\title{
No tyranny for failing Donald Trump - sad! Law, constitutionalism and tyranny in the twenty-first century
}

\author{
Aoife O'Donoghue*
}

Durham Law School

Correspondence email: aoife.o'donoghue@durham.ac.uk

\begin{abstract}
Donald Trump's presidency resulted in several accusations of tyrannical intent. The end of his term of office, and particularly the rioting of 6 January 2021 and the denial of the presidential election results, did little to dispel those accusations. Tyranny, while perhaps not fashionable as a basis of analysis, has a long-intertwined relationship with law and constitutionalism. This article uses Donald Trump's presidency to consider the relationships between tyranny, tyrannicide, law and constitutionalism. The article considers law and constitutionalism's role in both preventing and advancing the advent of tyranny and examines their limitations in stopping tyrannical intent. Public contestation is put forward as an equally significant bulwark against the advent of tyranny, but also a space under tremendous pressure during Donald Trump's presidency.
\end{abstract}

Keywords: Donald Trump; tyranny; constitutionalism; contestation; impeachment; tyrannicide.

\section{INTRODUCTION}

Tyranny is always relevant to debates on political power. In recent years, tyranny has been renewed as an analytical lens in 'the West', even though in reality seeing tyranny as newly relevant is a form of aphasia that ignores long-standing tyrannical regimes in the West (such as Belarus) and foundational tyrannical histories, especially in states with embedded imperial constitutions or founded on racial

\footnotetext{
Professor, Durham University (UK). My thanks to the School of Law, Queen's University Belfast, for the invitation to give the Stephen Livingstone Lecture and for the comments and questions from the audience. My thanks also to the staff of the Law School for the detailed comments at an earlier staff seminar. My thanks to Roger Masterman (Durham University), Fiona de Londras (Birmingham University) and Nicolás Perrone (Universidad Andrés Bello) for their comments upon earlier drafts. Any errors remain my own.
} 
and gender-based exclusions. ${ }^{1}$ Nonetheless, the contemporary rise of authoritarianism or illiberal 'constitutionalism' alongside existing long-term tyrannical orders raises concern. Donald Trump embodies these anxieties. ${ }^{2}$ This article does not ask whether Trump turned the United States (USA) into a tyranny, but rather whether Trump altered a system, already (always) under pressure, to instigate the processes of becoming a tyranny.

Tyranny cuts across governance structures and easily adapts to its context. No two tyrannies are the same; tyrants adapt tyrannical forms like silence, rule by law, fear, misogyny and illegitimacy to suit the context in which tyrants seek to maintain authoritarian rule. Using a taxonomy of tyranny, the article considers the collation of relational and shifting elements via an aggregation of events, practices and processes which indicates the presence of tyranny. Tyranny, like democracy or oligarchy, is an old concept and like these others, is as potentially present today as it was in Greek city states. ${ }^{3}$ Law, tyranny and constitutionalism are intimately linked. Constitutionalism and law hold dual functions, as tools of tyranny and buffers against tyranny's emergence. This mirrors law's duality as both a preventative mechanism and a device to perpetuate harms. Within these interactions, political contestation plays an essential role. Political contestation is vital to both tyranny's prevention and to its removal. The collective political action of a population is more significant to staving off or overthrowing tyranny than constitutional/legal forms. Attempts to blame the 74 million individuals who voted for Trump, even those that stormed the Capital, forget the circumstances, including institutional acquiescence, that led to his candidacy, the forms his presidency took and what has happened to the US public political space. ${ }^{4}$

Trump's clear tyrant-like approach makes tyranny an obvious choice as a lens through which to seek to understand his presidency and its broader significance. However, the analytical power of tyranny is such that it illuminates not only Trump and Trumpian politics as tyrannical, but also enables us to undertake a broader analysis that brings fresh perspectives to contemporary authoritarianism. Tyranny

1 S Pahuja, Decolonising International Law Development, Economic Growth and the Politics of Universality (Cambridge University Press 2011) 4; N Tzouvala, Capitalism as Civilisation: A History of International Law (Cambridge University Press 2020) 2; E W Said, Culture and Imperialism (Vintage 1994).

2 T Snyder, On Tyranny: Twenty Lessons from the Twentieth Century (Tim Duggan Books 2017) 9-13.

$3 \quad$ S Lewis, Greek Tyranny (Phoenix Press 2009) 31.

4 Federal Election Commission, Official 2020 Presidential General Election Results; E Hanley and D Smith, 'The anger games: who voted for Donald Trump in the 2016 election, and why?' (2018) 44 Critical Sociology 195. 
as a phenomenon is adaptable; it shifts form to the political system in which it is sought and enacted. US exceptionalism is such that its long history of deploying tyranny beyond its borders is generally recognised, but its internal tyranny is less commonly named as such. However, it is this US exceptionalism, and the USA's place in 'the West', that makes it important for us to turn the analytical lens of tyranny on Trump as well as on other 'obvious' candidates such as Duterte, Orban, Putin and Modi. In all cases, these tyrannical leaders seek to sustain a veil of legitimacy through claims of redefining constitutionalism, attempting to distinguish themselves from 'known tyrants' like Lukashenko or Kim Jong-un. Centring the USA and Donald Trump in an analysis of tyranny reorients a debate that is too often, and inaccurately, orientalised. 5

This article considers the ability of constitutions to withstand tyrannical aspirations and what other sources of political practice, in particular public contestation, are required to keep tyranny at bay. Like all concepts, tyranny only ever gives a partial account, and this piece does not exclude other explanations of events in the USA or elsewhere. ${ }^{6}$ Rather, in focusing on the relationships between tyranny, law and constitutionalism, it considers contemporary constitutional governance and its utility in preventing tyranny. This article begins by discussing tyranny, before examining whether its tendrils are identifiable in the US system. ${ }^{7}$ The piece then examines Trump's presidency before considering what lessons may be learned from his time in office.

\section{TYRANNY}

Definitions of tyranny are rare, nonetheless a taxonomy of its characteristics is possible and includes illegitimacy, silence, rule by law, fear, gendered and bureaucratic governance which may be beneficent, but the ultimate benefits always come to the tyrant and their cadre. Identifying tyranny requires sufficient latitude so that regimes qualify but with appropriate specificity to not encompass mere poor governance. Tyranny is about more than Nero, Stalin, cruelty or conspicuous consumption. While these are bad, the specific badness is

5 E W Said, Orientalism: Western Conceptions of the Orient (Knopf Doubleday 2014) 31-49; A Çirakman, 'From tyranny to despotism: the enlightenment's unenlightened image of the Turks' (2001) 33 International Journal of Middle East Studies 49.

6 See, for instance, C Salmon, 'Trump, fascism, and the construction of "the people”: an interview with Judith Butler' 29 September 2016.

7 Bonnie Honig argues there is a rich strain of monarchism and tyranny within the US Constitution: Bonnie Honig, Shell-Shocked Feminist Criticism after Trump (Fordham University Press 2021) 5. 
not what concerns scholars. On occasion tyranny is dismissed as mere incompetence or malevolence. While it takes such forms, they are not definitional. Illiberal constitutionalism, absolute constitutionalism, authoritarianism, Bonapartism, Caesarism or even totalitarianism are forms of tyranny adapted to their political contexts. ${ }^{8}$

Google Books' Ngram gives a partial history of tyranny's invocation. ${ }^{9}$ As a word, 'tyranny' peaked in use in 1785, just before the Federalist Papers were published, followed by a steep decline before rising again from the mid-1980s onwards. 'Tyrant' has two peaks, 1589 and 1787, and then follows a similar pattern. ${ }^{10}$ Bonapartism and Caesarism emerge in the early 1800 s and remain more popular than tyranny; totalitarianism, while briefly cited in the late 1700s, increased dramatically in the early 1920s before steadily declining after 1949 and then increasing again after 1979.11 The outlier is authoritarianism, whose use begins in the early 1900s and remains on an upward trajectory. ${ }^{12}$ Authoritarianism is evidently the twentieth and twentyfirst-century word of choice for overwhelming power.

Descriptive choices vary across political events, but overweening power is a constant source of debate. Specific invocations of tyranny as a distinct concept are valuable not because other words have different meanings, but because of tyranny's specific relationship with law, constitutionalism and legitimacy. ${ }^{13}$ Tyranny comes in many modes, informed by the political, cultural, social, and legal context in which it arises, and other terms may be useful in describing, for instance, personality-driven power - Bonapartism or Caesarism - an ideologicaldriven structure encompassing the entirety of life - totalitarianism or a form of overbearing power seeping through all power structures within a society - authoritarianism. None of these divisions are strict and, rather, fluctuate across contexts. Tyranny encompasses each of these modes, but also brings debate back to the liberal construction of whether law and constitutionalism may minimise it.

Tyrannical debate, by specifying a groups' proclivity for tyranny, informs how we construct groups, be they women, majorities or

8 M Richter, 'A family of political concepts: tyranny, despotism, Bonapartism, Caesarism, dictatorship, 1750-1917’ (2005) 4 European Journal of Political Theory 221.

9 Google Ngram search for 'tyranny'.

10 Google Ngram search for 'tyrant'.

11 Google Ngram search for 'totalitarianism'.

12 Google Ngram search for 'authoritarianism'.

13 Arendt would disagree, $\mathrm{H}$ Arendt, The Origins of Totalitarianism (Harcourt 1951) 6 . 
those under Eurocentric gazes. ${ }^{14}$ Tyranny underpins how liberal constitutionalism disregards certain groups, like minority elites, as problematic by minimising their proclivities towards power. ${ }^{15} \mathrm{~A}$ long-held idea that all are tyrants in waiting emerges from Western gendered, religious, cultural and historically specific ideas of power and Aristotelian political action where humans tend toward rather than choose roles. ${ }^{16}$ But doing so substitutes character or gender types for specific actions. Tyranny has global reach. It evolved at distinct moments across multiple geographic spaces, and, while the focus here is on Western political theory, it is not a western innovation. Second, Western imperialism (including its contemporary form) used and exported both its variety of tyranny and liberal constitutionalism. ${ }^{17}$

To fully understand the role of constitutionalism and contestation, tyrannicide, tyrannophobia and tyrannophilia are also important. Tyrannicide is parasitic, relying on tyranny's illegitimacy for its legitimacy and on tyrannicides to not themselves become tyrants. Tyrannicide encompasses a range of actions up to and including violence, but democracy and processes such as impeachment diminish that space. ${ }^{18}$ Hobbes devised tyrannophobia to describe those who feared strong sovereigns or sought substantive democracy and argued that it was their foolish fears that lead to dissent and civil war. ${ }^{19}$ Locke, conversely, suggested that tyranny is always extant and vigilance necessary to prevent its emergence. ${ }^{20}$ Accusing others of foolish fears or pointing to a system's ostensible ability to withstand tyranny while not recognising systemic gender or racial tyranny is an easy silencing tool and partially responsible for the rise of paradoxes such as authoritarian constitutionalism. Tyrannophilia is an old phenomenon, dating to Plato in Syracuse and his ill-fated attempt to create a

14 T Nyirkos, The Tyranny of the Majority (Routledge 2018) 1-3; E W Said, Orientalism: Western Conceptions of the Orient (Knopf Doubleday 2014) 31-49; L Bradshaw, 'Tyranny and the womanish soul' in T Koivukoski and D Tabachnick (eds), Confronting Tyranny: Ancient Lessons for Global Politics (Rowman \& Littlefield 2005) 161.

15 R A Dahl, A Preface to Democratic Theory (University of Chicago Press 2006) 9-10.

16 C Epstein, Birth of the State: The Place of the Body in Crafting Modern Politics (Oxford University Press 2021) 24.

17 L Colley, The Gun, the Ship, and the Pen: Warfare, Constitutions, and the Making of the Modern World (Liveright 2021).

18 F L Ford, Political Murder: From Tyrannicide to Terrorism (Harvard University Press 1987) 2; S K Brincat, “Death to tyrants": the political philosophy of tyrannicide-part I’ (2008) 4 Journal of International Political Theory 212.

19 T Hobbes, Leviathan (Clarendon Press 1909) 253.

20 J Locke, The Second Treatise on Government (Tegg \& Co London 1823) 201. 
philosopher tyrant, but named by Mark Lilla. ${ }^{21}$ A tyrannophile is a theorist who considers a specific tyrannical regime as an avatar to fulfil their own theoretical ambitions, which align with the regime's creed. The theorist allies with the tyranny to see their ambitions fulfilled.22 Tyrannicide, tyrannophobia and tyrannophilia are tied to each other and form part of a tyrannical political landscape.

\section{TYRANNY, LAW AND CONSTITUTIONALISM}

Two elements are critical to preventing modern tyranny: contestation and substantive constitutionalism. Montesquieu, Rousseau, the Federalists and Locke were the first to suggest that modern constitutionalism offered the possibility of preventing tyranny. ${ }^{23}$ Arendt showed that the politically active individual is essential, and Dahl argues that polyarchal democracy, a combination of popular sovereignty, political equality and majority rule, is key. ${ }^{24}$ But to be politically active one has to access the political sphere, which includes access to information and to knowledge of your governance structures, knowledge of what your constitution says and access to facts/truth. Arendt, Dahl and Machiavelli agree that, while legal formulations are important, what is essential is a network of habits and attitudes held by a politically active individual. In other words, it is the nexus between constitutionalism and the politically active system that prevents tyranny.

When prevention fails, tyrannicide comes to the fore. The legitimacy and duty to remove tyrants is rarely repudiated. ${ }^{25}$ Three questions are critical: is there a tyranny; whose duty is it to remove the tyrant; and then what actions may be taken? Modern constitutionalism gives partial answers. The Federalists sought to constitutionalise it through regular elections and formalised processes like impeachment which give constituted power-holders methods to tackle the (potential)

21 M Lilla, The Reckless Mind: Intellectuals in Politics (re-issue, New York Review of Books 2016) 210-211.

22 T Koivukoski, 'The education of a tyrant' in Koivukoski and Tabachnick (n 14 above) 197; M Kenny 'Reckless minds or democracy's helpers? Intellectuals and politics in the twentieth century' (2004) 3 Contemporary Political Theory 89.

23 Colley (n 17 above); A Rana, The Two Faces of American Freedom (Harvard University Press 2010) 3; M Astell, Political Writings (Cambridge University Press 1996).

24 R A Dahl, Democracy and its Critics (Yale University Press 1989) 27-28, 18; H Arendt, 'The great tradition: I. Law and power - Hannah Arendt's centenary: political and philosophical' (2007) 74 Social Science 713-726, 722. J Canning, A History of Medieval Political Thought (Routledge 2005) 113. 
tyranny. ${ }^{26}$ Other common constitutional features, such as judicial review or term limits, also forestall tyrannical ambition. A threshold for violent rebellion or revolution remains, though it is increasingly of last resort, but one held by constituent power-holders and recognised in legal forms such as remedial or anticolonial self-determination or anti-apartheid movements. 27 Albeit, this does not always legitimate violence by either the constituents (though it does not rule it out) or by the international community entering into humanitarian intervention to 'save' a population. ${ }^{28}$ The nexus between the constituent and the tyrant is critical: it is their right and their duty to remove the tyrant, and it is for them to determine the legitimate means of doing so. ${ }^{29}$

However, constitutionalism's relationship with tyranny far predates the Federalists, or the theorists of pre-revolutionary France. 30 This longer history points to the ways in which tyranny emerges from and through law. Tyranny emerged in archaic Greece, and by the classical period its links to legitimacy and law were well embedded. ${ }^{31}$ The early emergence of tyrannicide and legal immunities in Greek city states further attest to their close relationship. ${ }^{32}$ In Rome, Sulla, Julius Caesar and Augustus sought as leaders to hollow out their political offices and achieved this partially through law. ${ }^{33}$ Following Julius Caesar's assassination, Cicero argued that he had held illegitimate authority, an argument followed by the Roman Senate as it outlawed the office of dictator. ${ }^{34}$ During the European medieval era, associations between il/legitimacy and tyranny/tyrannicide became bound to

26 US Constitution, art II, s 4; D George, 'Distinguishing classical tyrannicide from modern terrorism' (1988) 50 Review of Politics 390, 390, 407.

27 Neelam Srivastava, 'Towards a critique of colonial violence: Fanon, Gandhi and the restoration of agency' (2010) 46 Journal of Postcolonial Writing 303; A Anghie and B S Chimni, 'Third World approaches to international law and individual responsibility in internal conflicts' (2003) 77 Chinese Journal of International Law 2; B Rajagopal, International Law from Below: Development, Social Movements and Third World Resistance (Cambridge University Press 2003); J Dugard and J Reynolds, 'Apartheid, international law, and the occupied Palestinian territory’ (2013) 24 European Journal of International Law 867.

28 C R G Murray and A O’Donoghue, 'Towards unilateralism? House of Commons oversight of the use of force' (2016) International and Comparative Law Quarterly 305.

29 A Orford, Reading Humanitarian Intervention: Human Rights and the Use of Force in International Law (Cambridge University Press 2003).

30 Colley (n 17 above).

31 M Lane, Greek and Roman Political Ideas (Penguin 2014) 75.

32 D Teegarden, Death to Tyrants! Ancient Greek Democracy and the Struggle against Tyranny (Princeton University Press 2013) 5.

33 J Rich, 'Making the emergency permanent: auctoritas, potestas and the evolution of the principate of Augustus' (2012) Des réformes augustéennes 37-121, 43.

34 Cicero, On Duties (Cambridge University Press 1991) 96. 
theocratic monarchs and the question of who possessed the right and duty to overthrow a tyrant, if such a right and duty existed. 35 While Bartolus and Machiavelli framed their debates on who held the right to make law and whether it was possible to be legitimately above the law, the nexus between law and tyranny never lost its centrality. 36

Across these writings, illegitimacy emerges across three different areas, all of which are concerns of law and constitutionalism, namely, coming to office, altering offices while in power or the use of power outside of constitutional structures - for instance, leveraging economic power or non-state violence. These are not always referred to as tyranny, although they should be. Strauss argues that we are incapable of naming a tyranny, and descriptions of regimes as post-constitutional or illiberal rather than tyrannical attest to his claim. ${ }^{37}$ Terms such as authoritarian or illiberal constitutionalism form part of the legal veil tyrants use to cloak their actions in apparent constitutional/legal legitimacy. Kovács and Tóth rightly refer to contemporary European authoritarianism, in which regimes lay claim to being both constitutional and tyrannical, as 'constitutional barbarism'.38 However, understanding the misnaming of tyranny as a form of constitutionalism requires us to recognise that the fissures which allow such misnomers to continue are often rooted in claims that democratic legitimacy is unnecessary to constitutionalism; a claim that is found both in states with shorter records of substantive democracy and those with imperial constitutions. ${ }^{39}$ Such equivocation towards the necessity of democracy to constitutionalism creates space in which authoritarian or illiberal regimes that violate other normative constitutional norms can easily fit and seek to disguise their tyranny in plain sight. Decoupling constitutionalism from democracy enables the so-called 'secret tyrant' who maintains an outward appearance of

35 C Nederman, 'Tyranny' in Encyclopaedia of Medieval Political Thought (Springer 2011) 1347.

36 Bartolus of Sassoferrato, On the Tyrant (J Robinson (trans) 2012); G Pedullà, 'Machiavelli's Prince and the concept of tyranny' in N Panou and H Schadee (eds), Evil Lords: Theories and Representations of Tyranny from Antiquity to the Renaissance (Oxford University Press 2018) 191, 207.

37 L Strauss, On Tyranny including the Strauss-Kojève Correspondence, V Gourevitch and M S Roth (eds) (University of Chicago Press, 1961) 22.

38 Kriszta Kovács and Gábor Attila Tóth, 'The age of constitutional barbarism' (Verfassungsblog, 7 September 2019); Gábor Attila Tóth, 'Constitutional markers of authoritarianism' (2019) 11 Hague Journal on the Rule of Law 37.

39 Karolina M Milewicz, Constitutonalizing World Politics: The Logic of Democratic Power and the Unintended Consequences of International Treaty Making (Cambridge University Press 2020) 26-27; C Murray and T Frost, 'The Chagossians' struggle and the last bastions of imperial constitutionalism' in S Allen and C Monaghan (eds), Fifty Years of the British Indian Ocean Territory: Legal Perspectives (Springer 2018) 147. 
legitimacy while turning the system to their benefit. 40 At the same time, tyrannophobia prevents direct accusations of tyranny for fear of looking foolish, as Hobbes would have it. Tyrants understand this. They perceive value and importance in a specific form of governance constitutionalism - steeped in law and only emerge from the cloak of legitimacy afforded by law and constitutionalism when their superficial commitment no longer serves their purposes.

This relationship between law, constitutionalism and tyranny is bolstered by (neo)imperialist international habits of naming some states as 'failed or outlaw states', with attendant loss of status, and others as rearticulations of constitutionalism with continued inter-state esteem and maintained status in and beyond law. ${ }^{41}$ International law asks only whether there is a government and not its form. Constitutionalism and statehood are not synonymous, nonetheless a line between states with dispersed governance as automatically negative and tyrannies as acceptable is evident. 42

Within contemporary tyranny, constitutional structures often remain intact. There may be separation of powers, but the question is whether there is a substantive division in terms that produces a check on constituted power. ${ }^{43}$ A simulacrum of division and check is the most common iteration of modern tyranny. There may be judges or legislators, but if their touchstone is the whim of the ruler rather than the demos or constitution, they are a sham check. Contemporary tyranny can also emerge from temporal and functional changes to political office. Office-holders begin to accumulate additional functions, and there are often creative reinterpretations of the offices of president and prime minister to shift power between the two. This is sometimes accompanied by constitutional changes undertaken in the absence of contestation from other constituted power-holders, or within a denuded public sphere. These are neither 'post-constitutional' or newly formed constitutional spaces. ${ }^{44}$ To accept the latter in particular is to accept that a tyrant can create legitimacy through their own tyrannical action.

Even though law is everywhere in tyrannies, in these contexts, law's creation, enforcement and adjudication cannot meet even thin conceptions of the rule of law. While the rule of law often has

40 Bartolus of Sassoferrato (n 36 above) 4-5; C de Montesquieu, The Spirit of Laws, Thomas Nugent (trans) (Batoche Books 2001) 322.

41 Kovács and Tóth (n 38 above); Tóth (n 38 above).

42 Montevideo Convention on the Rights and Duties of States 1933; T Ginsburg, 'Authoritarian international law?' (2020) 114 American Journal of International Law 221.

43 C Möllers, The Three Branches: A Comparative Model of Separation of Powers (Oxford University Press 2013); J N Shklar, Montesquieu (Oxford University Press 1987) 85. 
negative consequences for those not coming within the bounds of liberal constitutionalisms' citizen actors and continues to have a role in (neo)imperialism, nonetheless it retains important functions as regards constituted power-holders. ${ }^{45}$ The tyrant is the arbitrator of the common good, combined with an ability to not just be above the law but to be the law's ultimate interpreter of meaning and value. In this setting, law is the will of the ruler and not of the demos and is not subject to contestation. For the tyrant, nurturing public contestation is dangerous, not because, as Hobbes argues, it risks the common good and any demand for it is mere tyrannophobia, rather because for the tyrant it risks making plain that rule by law subsists. 46

In tyrannies, law creation becomes the tyrant's whim, unfettered from the demos and attuned to the tyrant's own needs. Incrementally, law no longer incumbers political action, creating space for sudden changes to core structures, unconstrained by processes of accountability, alongside slower modifications that over time alter the tenor of the system. As the law serves the tyrant's definition of the common good, the tyrant decides what is necessary, including what constitutes accurate constitutional interpretation and desirable constitutional change. As the ultimate authority and adjudicator of law, the tyrant, in accordance with their decision on the common good, chooses when to follow law. 47 Where this produces positive outcomes, like economic prosperity or the safeguarding of some rights, this emerges from the tyrant's beneficence and the tyrant remains at liberty to change their mind. 48 The common good and the laws needed to establish it remain the tyrant's whim. 49

Constructing the demos within a tyranny is linked to structure and beneficence, and in particular to majorities and minorities. Though the substantive debate is older, John Adams coined the phrase 'tyranny of the majority', and in the period when democracy first emerges in the

45 Mark Brown, “"An unqualified human good”? On rule of law, globalization, and imperialism' (2018) 43 Law and Social Inquiry 1391; U Mattei and L Nader, Plunder: When the Rule of Law is Illegal (Wiley 2018). Hobbes (n 19 above) 253.

47 Ibid 163; H Arendt, The Origins of Totalitarianism (Harcourt 1951) 374.

48 H Jones, 'Property, territory, and colonialism: an international legal history of enclosure' (2019) 39 Legal Studies 187; Frank I Michelman, 'Liberal constitutionalism, property rights, and the assault on poverty' (2011) 22 Stellenbosch Law Review 706; David E Bernstein and Ilya Somin, 'The mainstreaming of libertarian constitutionalism' (2014) 77 Law and Contemporary Problems 43.

49 R Boesche, 'Aristotle's science of tyranny' (1993) 14 History of Political Thought 1,6 . 
Atlantic World fear of the demos kicks in.50 Mill, Strauss and others replicate this fear and often combine and (purposively) confound negative populism that merges divisional politics that places blame for economic (or other) hardships on particular groups alongside modern forms of bread and circuses with positive populism that responds to genuine requirements of the masses. ${ }^{51}$ In reality, (elite) minorities wielding negative populism is far more commonplace but rarely gets the press that potential majority tyranny receives. Forefronting majorities as innately problematic gives credence to arguments for 10 per cent less democracy. ${ }^{52}$ It is essential to not confuse manipulation by elite minorities through negative populism with democratic majoritarianism, for to do so is to blame the masses for the faults of a (tyrannical) elite. 53

For the tyrant, diminishing individual and collective capacity for contestation, and so the possibility of contesting a tyrant's rise, is essential. Law forms an important element of the production of silence and the diminishing of public contestation. Harmony and tranquillity appear to exist alongside cacophonies of adulation. 54 Violence or its threat produces silence and turns a population's attention toward the private sphere and away from public contestation, making it fearful that the tyrant will use their power, or perhaps their Twitter feed, to set their followers upon the populace. Emptying the public sphere takes time. In Republican Rome, it took a century between Sulla's dictatorship and Augustus's rise to create a new order. Emptying the public sphere takes many forms, from poverty, to fear of economic or status loss, or fear of coming to the attention of the tyrant. Taking decisions away from the public sphere and into the realm of expertise and non-political spheres, to create what Hirsch describes in the legal sphere as a juristocracy, has similar results. ${ }^{55}$ Slowly reducing sites of

50 J Adams, In Defence of the Constitutions of Government of the United States of America (1787).

51 Nyirkos (n 14 above) 1-3; R Boesche, Theories of Tyranny: From Plato to Arendt (Penn State Press 2010) 37-38; C Mouffe, For a Left Populism (Verso 2018).

52 Garrett Jones, 10\% Less Democracy: Why You should Trust Elites a Little More and the Masses a Little Less (Stanford University Press 2020).

53 Honig (n 7 above) 142.

54 N Machiavelli, Discourses on Livy (Penguin 2013 [1531]) 18-25; H Arendt, The Promise of Politics (Schocken 2009) 78; R Boesche, 'Fearing monarchs and merchants: Montesquieu's two theories of despotism' (1990) 43 Political Research Quarterly 741; John of Salisbury, Policraticus: Of the Frivolities of Courtiers and the Footprints of Philosophers, C J Nederman (trans) (Cambridge University Press 1990) 231.

55 R Hirschl, Towards Juristocracy: The Origins and Consequences of the New Constitutionalism (Harvard University Press 2007); Jones (n 52 above); T Paine, 'Common sense' in M D Conway (ed), The Writings of Thomas Paine Volume I 1774-1779 (Putman's Sons 1894) 112. 
information and the character of that information or access to quality education and producing in its stead an independent 'reality' reduces the capacity for debate and contestation so that, as Arendt argues, 'reality is no longer experienced'. 56 Once reality is corrupted, public contestation becomes impossible.

\section{TRUMP THE TYRANT?}

Donald Trump has not yet turned the USA into a tyranny recognisable to liberal constitutionalism. It is not clear that he seeks to be a tyrant, and in truth he, his personality and his wealth are only a partial font of Trumpism. It is vital to not take Trump as anything more than he is: unideological, ridiculous, but successful in achieving the office of the President of the USA. Trump has, however caused much harm, by separating families at US borders, by turning women's stories of abuse into fake news, by undermining Black Lives Matter, and by mishandling the Covid pandemic. These harms build on pre-existing gender, economic and racial harms that the US already grapples with. Trump did not create misogyny and racism but used a misogynist and racist platform of divisional populism for his own ends. 57

The question, then, must be whether Trump altered a system already under pressure to instigate and/or expedite becoming a tyranny. 58 There are many incidences during Trump's presidency that suggest tyrannical intent and covering them all is unfeasible. Nor is there a 'smoking gun' that catches the Trump administration as wannabe tyrants. Rather, it is a collection of incidences that when brought together expose the possibility of tyranny within an already-denuded political space and with the support or acquiescence of other political figures. Pre-existing problems in the US political-legal structure created a space for Trump's emergence, and it is what Trump did within that space that is important.

Miller argues that:

Trump's attitude to truth while campaigning was that of a sophist: someone who is indifferent to the truth, using words only to acquire money, fame, and power. When he became president, however, his attitude changed to that of the tyrant ... someone who uses power to assert control over the 'truth.' In other words, by the repeated statement of manifest falsehoods, he drew a circle around himself, forcing S Collini (ed) (Cambridge University Press 1989) 75; Arendt (n 47 above) 169. 
others to choose between submission to his will and recognition of an independent reality. 59

This is an integral thread of Trump's presidency and, according to the Washington Post, the administration made over 33,000 false or misleading claims during his tenure, accelerating in his final months. This alternative reality included whether or not it rained.60 Institutional duplicity continues both via Trump and by some members of the Republican Party at both state and federal levels. ${ }^{61}$ Trump's post-presidency website is a repository of an alternative reality. ${ }^{62}$ The extent that the administration could mislead with no repercussions has direct consequences for the public sphere. US law, according to Sunstein, cannot tackle political lying and in particular how political dishonesty operates in the twenty-first century, via social media. ${ }^{63}$ The Trump administration used this legal vacuum to create its independent reality to its great advantage.

If reality underpinning discussion erodes beyond typical political positioning, public contestation becomes denuded. There are two realities, including two legal realities. Law is contingent, which makes lies about it easier. Nonetheless, Trumps' relationship to the realities (rather than truth) of US constitutional and wider law played a significant role in what unfolded. Trump made repeated statements about environmental law, trade law, crime, healthcare and abortion access that were inaccurate. ${ }^{64}$ These misleading claims created a legal reality where his triumphs and failures were all couched in law that either did not exist or differed from that described. This makes contestation all but impossible: how to debate legal reform if the basis for that discussion is entirely without substantiation. There may be a cacophony of noise, but actual political debate with the Trump administration did not exist.

Trump repeated false claims about the US Constitution, about the Democratic Party's attempt to overthrow the Constitution, the extent of his executive power, the role of the judiciary, impeachment and about the Constitution's history. 65 Trump's 1776 Commission

59 P Lee Miller, 'Truth, trump, tyranny: Plato and the Sophists in the era of "alternative facts" in A J Torres and M B Sable (eds), Trump and Political Philosophy: Leadership, Statesmanship, and Tyranny (Springer 2018) 17.

60 Washington Post Fact Check \#14, D Trump (21 January 2017).

61 G Kessler, 'Trump made 30,573 false or misleading claims as president. Nearly half came in his final year' (Washington Post, 23 January 2021).

62 See 'The 45th President of the United States' The Office of Donald J Trump.

63 C R Sunstein, Liars: Falsehoods and Free Speech in an Age of Deception (Oxford University Press 2021).

64 The Washington Post has a searchable database: Fact Checker.

65 Ibid. 
is a rewriting of constitutional, legal, political and social history. 66 The report ignores manifest injustice, or slavery's part in the USA's founding. 67 Rather, the 1776 Commission Report follows Trump's will to create an alternate history where the Constitution weakened rather than entrenched racism. This alternative constitutional history resituates Martin Luther King's protests and the necessity of the Civil Rights movement as fulfilling the Constitution's purposes. 68 The history of constitutional law becomes the history of Trump's will. Constitutional scholarship - legal and historical - should not buttress a system's legitimacy by ignoring how it evolved, including tyranny through slavery or disenfranchisement. By repeatedly attempting to assert a truth about law and the Constitution, Trump forces a choice between his will and independent reality but also delegitimises a history of protest and campaigning critical to US constitutional history. Alternative realities force choices between Trump's legal and political world and independent reality and are essential to understanding other aspects of the administration. In the context of the Black Lives Matter movement, the deracialisation of historic protest directly impacted on perceptions of that movement. They were no longer the heirs to Martin Luther King, but rather are in opposition to his legacy. Such strategies delegitimise the public space for contestation by creating the space for tyranny to emerge.

If tyrants enter office to gain benefits, be that economical, psychological, or ideological, the question becomes: what benefited Trump and his cadre? Two potential benefits come to the fore: economic advantages and immunity. Kuhner describes Trump's crony capitalism during his time in office. ${ }^{69}$ Trump's Finance Bills increased the wealth of people who resembled him, the wealth-dominating classes. ${ }^{70}$ There were some benefits for the wider population, for instance, employment rose, but Trump also made exaggerated claims about his management of the US economy. ${ }^{71}$ Most gains went to those like Trump, already wealthy individuals, whose prosperity increased. There were also many conflicts of interest between his and his family's businesses and the office of president. Citizens for Ethics, a non-partisan corruption

66 The 1776 Report was almost immediately withdrawn from the White House website when the Biden Administration took over.

67 Rana (n 23 above).

68 R Houghton and A O'Donoghue, 'Manifestos and counter-manifestos: an explainer for the 1776 Commission' (Critical Legal Thinking, 21 January 2021).

69 T K Kuhner, Tyranny of Greed: Trump, Corruption, and the Revolution to Come (Stanford University Press 2020); for a broader view of tyranny, law and the global economy, see L Wenar, Blood Oil: Tyrants, Violence, and the Rules that Run the World (Oxford University Press 2018).

70 Consolidated Appropriations Act, 2018 Pub L 115-141.

71 Washington Post Fact Check \#30,562; \#30,557. 
watchdog counted 3400 visits by foreign government officials to Trump-owned properties, including Mar-a-Lago, taxpayer spending at Trump businesses, and Trump's promotion of his businesses. ${ }^{72}$ There are also his ongoing battles regarding his tax returns and broader financial dealings, which includes cases involving the House Ways and Means Committee and Trump's refusal to pass documents to it. ${ }^{73}$ The US Supreme Court held in Trump $v$ Mazars that while separation of powers issues were raised, it was not a question of executive privilege, as Trump claimed, and Congress may request, with legitimate reason, documents from a president. ${ }^{74}$

The second benefit derives from the immunities and pardoning powers of which Trump took full advantage. The presidential power to pardon rests in article II, section 2 of the US Constitution. ${ }^{75}$ The suggestion that he would pre-emptively pardon himself and his family before leaving office did not come to fruition, but Trump pardoned several individuals either connected to him and/or who were charged or convicted of financial crimes.76 This includes Steve Bannon (who is subject to fraud charges), Kwame Kilpatrick (found guilty of racketeering and extortion), Paul Manfort (guilty of financial crimes), Anthony Levandoswki (guilty of stealing trade secrets) and Duncan Hunter (convicted of stealing campaign funds). ${ }^{77}$ Others pardoned include four Blackwater guards found guilty of murdering Iraqi citizens. Their pardons potentially violate the USA's international legal obligations. 78 Some pardons were connected to the 2016 presidential election or the administration's early period, including that of Michael Flynn, retired army lieutenant general and former National Security Advisor, guilty of making false statements to US federal investigators, alongside political consultants Roger Stone and George Papadopoulos, both guilty of several crimes regarding Russian involvement in the 2016

72 Citizens for Ethics; Honig (n 7 above) 30-35.

73 Committee on Ways and Means v US Department of Treasury.

74 Donald J Trump, et al $v$ Mazars USA, LLP and Committee on Oversight and Reform of the US House of Representatives 591 US 140 S Ct 2019.

75 US Constitution, art II, § 2; B C Kalt, 'Pardon me?: the constitutional case against presidential self-pardons' (1996) 106 Yale Law Journal 779.

76 F O Bowman III, 'Presidential pardons and the problem of impunity' (2021) 23 NYU Journal of Legislation and Public Policy; Lauren Mordacq, 'Fake news: the president has the "absolute right" to pardon himself' (2020) 13 Albany Government Law Review Online.

77 Pardons Granted by President Donald Trump; Ken Kurson, a friend of the Trump family, found guilty of cyberstalking was pardoned.

78 'Issuing several pardons, President Trump intervenes in proceedings of US troops charged or convicted of acts amounting to war crimes' (2020) 114 American Journal of International Law 307; United Nations High Commissioner for Human Rights Press Release, Press Brief on the United States (19 November 2019). 
US presidential election. Presidential pardoning had already grown to encompass direct political pardons, and Trump took advantage of this trend to extend it substantially. ${ }^{79}$

Coupled with the near 200 pardons during Trump's final two months in office was the rush to execute prisoners. Excessive punishment and pardoning are often tyrannical traits. ${ }^{80}$ At the direction of the executive, 10 people were executed, a break in the tradition of pausing executions before a new President takes office as well as a moratorium on federal executions in place since 2003. The US Supreme Court denied three stay requests and a stay of execution granted by the 7th Circuit Court of Appeals. ${ }^{81}$ Going ahead with such executions is a call back to practices of bread and circuses in an all too gruesome fashion; executions to appease a base of voters and an inhumane benefit of the common good. It also reveals the weakness in constitutional conventions, especially those related to protecting human rights, here the fundamental right to life, in the context of executive power. Siegal argues that the 'disregard of political norms that had previously constrained presidential candidates and Presidents, and his flouting of nonlegal but obligatory "constitutional conventions" that had previously guided and disciplined occupants of the White House' was one of the most troubling parts of his administration. 82 It shows the vulnerability of relying on such political/legal norms to reign in an administration that can simply choose to ignore them.

Connected to the pardoning/execution axis is the role of the Department of Justice and the Executive Branch regarding investigations. Early in the Trump administration there was a high proportion of investigations into Trump's associates, which slowly lessened, particularly after William Barr became Attorney General. James Comey's firing as head of the Federal Bureau of Investigation (FBI), Bowman describes as an 'emasculation of an executive and congressional mechanism for investigating, and where appropriate punishing misconduct by the president and his allies' ${ }^{83}$ Congress, civic watchdogs and state justice systems continue to investigate, though the Trump administration refused to cooperate. ${ }^{84}$ For example, there are two congressional investigations into an Inland Revenue Service whistle-blower's allegations that a Trump political appointee at the

79 Bowman (n 76 above).

80 John of Salisbury (n 54 above) 51-55.

81 Barr, Attorney General, et al v Hall, Orlando Order List: 592 US.

82 Neil S Siegel, 'Political norms, constitutional conventions, and President Donald Trump' (2018) 93 Indiana Law Journal 177.

83 Bowman (n 76 above).

84 Donald $J$ Trump $v$ Cyrus $R$ Vance, $J r 140$ S Ct 2412; 207, District Attorney of New York Statement. 
Treasury Department interfered with the audit of President Trump or Vice President Pence. 85

Several features can help us to understand the tyrannical context at play here. First is the relationship with law and constitutional enforcement as between the three branches of US Government, a point returned to regarding impeachment, the judiciary and the production of silence. Former FBI director Comey's firing made headlines, but there were other many replacements amongst the agencies of the executive branch, particularly amongst those with investigative powers. 86 The very public and humiliating firing of Comey, among others, produces fear of loss of position, a privatising of the administrative sphere of government which increasingly contained people holding back for fear of losing their jobs, or those happy to acquiesce to the Trump administration's desires or on board with Trump's objectives. This was accompanied by what Honig describes as Comey's feminisation, including during Senate Intelligence Committee hearings which used gender as an 'apparatus of power' to undermine Comey's credibility. 87 The apparent reduction in Department of Justice investigations also suggests the possibility that there was an understanding that the Trump administration's need to get its agenda done - the Trump view of the common good - was more important than investigating potential crimes or malpractice in office.

Removing people who voiced opposition or obstructed their agenda was important to the administration. Comey's firing clarified that, if one disagreed with Trump, one should fear for one's job. Comey argues that his firing shows he was doing his job properly, while this may not be the measure, it is undoubtedly how both sides regarded the situation. 88 Political appointees are tied to their appointer, but these offices include independent functions inconvenient to Trump. Yet, there is little within the constitutional or legal structure which prevented the silencing and privatising of these spaces, partly because the very intention was to prevent the 'wrong' investigations from taking place. Nonetheless, political contestation withstood some incidences,

85 US Congress, House Ways and Means Committee, Donald J Trump, et al $v$ Mazars USA, LLP and Committee on Oversight and Reform of the US House of Representatives 140 S Ct 2019.

86 M Quinn, 'The internal watchdogs Trump has fired or replaced' (CBS NEWS, 19 May 2020) (listing five inspectors general - Intelligence Community, Transportation Department, Defense Department, Department of Health and Human Services, and State Department - fired or replaced by President Trump as of 19 May 2020); B McCarthy, 'Trump has pushed out 5 inspectors general since April. Here's who they are' (POLITIFACT, 19 May 2020).

87 Honig (n 7 above) 36-22.

88 J Comey, Saving Justice: Truth, Transparency, and Trust (Pan Macmillan 2021). 
particularly with Anthony Fauci. That Fauci remained in office, despite the Trump administration's continuing downgrading of the National Institute of Allergy and Infectious Diseases advice on Covid, and, of Fauci himself, suggests there were still restraints - though not legal ones - on Trump's actions. Trump retweeted posts with \#FireFauci, accused him of multiple mistakes and now indicates he might fire him if re-elected.89 Fauci's reputation and public confidence made him difficult to fire, proving contestation may succeed where law provides trifling safeguards. 90 If the intention was to create an executive administration in thrall to Trump, it only partially succeeded.91 The transition team eventually worked with Biden, and the Justice Department did not find any voter fraud to assist Trump's claims of a stolen election. ${ }^{92}$

On first examination, Trump's presidency seems very loud and far from silent. Yet, silencing occurred all the time. US media regulation is often light touch and freedom of expression sacrosanct, but newspapers, television and other news sources are still subject to regulation, with the critical exception of social media. ${ }^{93}$ Zick catalogues an 'extraordinary number of incidences in which the statements, actions, and reactions of Donald Trump, first as a candidate and then as president ... questioned or threatened First Amendment values and rights'.94 Several lawsuits regarding Trump's blocking of Twitter accounts and revocations of press credentials for White House correspondents as potential violations of first amendment rights are ongoing. 95

89 Katie Shepherd, John Wagner and Felicia Sonmez, 'White House denies Trump is considering firing Fauci despite his retweet of a hashtag calling for his ouster' (Washington Post, 13 April 2020); Josh Lederman and Kelly O’Donnell, 'White House seeks to discredit Fauci as coronavirus surges' (NBC News, 13 July 2020); William Cummings and Courtney Subramanian, "I appreciate the advice": Trump tells crowd chanting, "Fire Fauci!" to wait until after election' (USA Today, 2 November 2020).

90 D P Christenson and D L Kriner, 'Does public opinion constrain presidential unilateralism?’ (2019) 113 American Political Science Review 1071.

91 Cass R Sunstein and Adrian Vermeule, 'Presidential review: the president's statutory authority over independent agencies' (2021) 109 Georgetown Law Journal 637.

92 M Balsamo, 'Barr says Justice Department found no evidence of fraud that would change election outcome' (PBS News Hour, 1 December 2020).

93 Sunstein (n 63 above) 103; S Fish, There is No Such Thing as Free Speech (Oxford University Press 1994); A Meiklejohn, Free Speech and its Relation to Self-Government (Harper 1948).

94 T Zick, The First Amendment in the Trump Era (Oxford University Press 2019) xii.

95 Knight First Amendment Institute v Trump Docket nos 1:17-cv-05205; CNN v Trump 1:18-cv-02610-TJK. 
Social media plays an important role in contestation and especially in a publicly active sphere connecting individuals across networks, but it remains a largely unregulated space, especially with regards to hate speech and false information. 96 Trump adroitly used law's absence, particularly on Twitter, to silence. ${ }^{77} \mathrm{He}$ used the official Office of the President Twitter account to retweet his personal account, fusing the two entities. Fear of coming to Trump's attention and the Twitter onslaught that might follow had a chilling effect. During the pandemic, Fauci and his family were harassed and received many death threats. 98 Reich describes how Trump used both the presidency and Twitter to silence private citizens, companies, reporters, union representatives, officials like Fauci and, in some circumstances, other branches of government.99 Reich details how, when an 18-year-old woman who attended a political forum told Trump he was not 'a friend to women', Trump tweeted that she was an 'arrogant young woman'.100 Immediately, she began receiving violent, threatening messages, including of rape, attempting to silence her or force her to recant. Trump did not tweet such specific threats, but rather used this nongovernmental power based within an unregulated space to point his followers to this woman. Trump also pointed Twitter towards members of the judiciary. Judge James Robart gave a rescinding order against the Muslim immigration ban, Trump on Twitter branded him a 'socalled judge' - presumably, a real judge is one that does not contradict the executive - and what followed were similar threats to Robart's safety, many coming from Russia. ${ }^{101}$ Trump endorses the threatening and violent acts of his supporters and Russian bots, using the 'mob' which he partially created through divisive populism to achieve silence. This divisional populism turns contestation upon itself and curtails the

96 C R Sunstein, Republic: Divided Democracy in the Age of Social Media (Princeton University Press 2018).

97 Alexandra A Siegel et al, 'Trumping hate on Twitter? Online hate speech in the 2016 US election campaign and its aftermath' (2021) 16 Quarterly Journal of Political Science 71; Douglas B McKechnie, ‘@ POTUS: rethinking presidential immunity in the time of Twitter' (2017) 72 University of Miami Law Review 1.

98 'Fauci admits administration has restricted his media appearances, says he's not surprised Trump got COVID’ (60 Minutes, 19 October 2020).

99 Robert Reich, 'Trump's creeping tyranny' (8 December 2016). Honig describes a similar outcome when members of the administration would follow Trump's lead to bring down threats and protests for actions that were civil and ordinary: Honig (n 7 above) 59-67.

100 'Donald Trump attacked her on Twitter' (CNN News, 9 December 2016).

101 N Colarossi I, 'Russians sent thousands of threats against US Judge James Robart after Trump tweeted about him' (Newsweek, 19 February 2021); see also Judge Gonzalo Curiel, D Kellner, 'Donald Trump as authoritarian populist: a Frommian analysis' in J Morelock (ed), Critical Theory and Authoritarian Populism (University of Westminster Press 2018) 71, 76. 
politically active space by focusing it on hate and blame rather than at those who truly benefit from the system.

Unregulated social media is in stark contrast to the censoring of traditional media by curtailing its access, suggesting that violence against its members is acceptable, or openly mocking reporters with disabilities. ${ }^{102}$ Creating an alternative reality is partially achieved through the fake/failing news discourse but also goes back to Trump's trumpeting of the 'birther' conspiracies that undermined Obama's legitimacy as President. 103 The role of social media in spreading such conspiracies is acute. There are now conspiracies that claim Biden is not really the President, that he is filmed on a 'White House' film set and that mass arrests followed his inauguration. These are set alongside QAnon's alien conspiracies which Trump refuses to deny. This delegitimates both the Presidents before and after Trump. Social media and the media generally in the US are increasingly partisan and alternative facts or misleading claims take the place of a contested political sphere; thus silence is created. Social media is not so different from other news sources and can be positive, for instance, sharing information of police brutality, but the absence of regulation accelerates the denuding of the public sphere.

Societal, political and official violence are features of US politics and life. The everyday violence faced by African Americans at the hands of the state is well documented. ${ }^{104}$ Trump's close relationship with violence is not exceptional, but the objective of deployment of violence and the source of the violence sets it apart. Some of this emerged from his social media and his public statements. From the outset there was violence at Trump rallies. Protestors were harassed and sometimes assaulted. There are his rally speeches where he stated 'in the good old days this doesn't happen because they used to treat them very, very rough. And when they protested once, you know, they would not do it again so easily' or 'I'd like to punch him in the face I'll tell you.' 105 The violence is also indirect. The ramifications of his insistence on calling the Covid pandemic the 'Chinese virus' are still being felt in the mass increase in hate crime against the Asian American community in the USA.106

102 Ibid 73-74.

103 'Fact check: White House was not vacant for ten days after inauguration; nighttime darkness pre-dates Biden' (Reuters, 3 February 2021).

104 D W Carbado and P Rock, 'What exposes African Americans to police violence' (2016) 51 Harvard Civil Rights-Civil Liberties Law Review 159; N A Cazenave, Killing African Americans: Police and Vigilante Violence as a Racial Control Mechanism (Taylor \& Francis 2018).

105 G Lopez 'Don't believe Donald Trump has incited violence at rallies?' (Vox, 12 March 2016).

106 K Yam, 'Anti-Asian hate crimes increased by nearly 150\% in 2020' (NBC News, 9 March 2021). 
Trump's speech on 6 January 2021 and the extremist violence aimed at Congress - another branch of government - resulted in his second impeachment. Trump's political actions on 6 January used non-state violence as its tool. Although those that stormed the Capital were a small subset of his supporters, Trump felt they were a group he could wield against another part of the governance order.107 Trump's treatment of Vice President Pence in the midst of the speech is illuminating. He mentioned Pence 13 times, and the mob chanted 'hang Mike Pence' as it entered the Capitol, while in the midst of the violence Trump tweeted that Pence did not have the courage to do what he should have. ${ }^{108}$ This was a reference to Pence deciding he was legally bound to certify Biden's election as President. Pence chose the law rather than Trump's reality by voting to certify Biden's election, but, arguably, 147 Republicans who voted against it did not. Pence certified and attended the inauguration; therefore, the threat of violence did not work, but it is telling that Trump thought it might.

There is also less directly attributable violence. The far-right rally and counterprotests in Charlottesville are a prime example, but there were other incidences involving the Proud Boys (now declared a terrorist entity by Canada) and other extremist groups. ${ }^{109}$ Trump's non-condemnation, insistence that there are 'fine people on all sides' and suggestions that the Proud Boys should 'stand down and stand by', all point to a long-arm use of violence to achieve a political end.110 When examined in comparison to the state violence deployed against Black Lives Matter protestors, there is a clear distinction between those who are welcome to voice contestation and those who are not. Over the course of the administration there was a process by which violent/ military crackdowns became acceptable against those outside Trump's 'fine people' category. Those engaged in contestation and protest were teargassed, while those engaged in extremism were praised. Examining this alongside the use of racist rhetoric against Mexicans, Muslims and Chinese people, all of whom suffer increased hate crime,

107 August H Nimtz, 'The Trump moment: why it happened, why we "dodged the bullet", and "what is to be done?".

108 Sidney Blumenthal, 'The martyrdom of Mike Pence' (The Guardian, 7 February 2021).

109 Government of Canada, Public Works and Government Services Canada (3 February 2021), Canada Gazette, part 2, vol 155, no 2 'Regulations Amending the Regulations Establishing a List of Entities'.

110 US Presidential Debate (Corporation for Public Broadcasting, 29 September 2020); 'Full text: Trump's comments on white supremacists, "alt-left" in Charlottesville' (Politico, 15 August 2017). 
the divisional populism of the rhetoric is evident. ${ }^{111}$ This is intermixed with fear of Muslims and certain majority Muslim countries (but not Saudi Arabia) and an eliding of Islam with ISIS and Al-Qaeda. ${ }^{112}$ Fear of violence from extremist terrorism is genuine, however, it was rightwing terrorism and violence that was manifested at the end of Trump's administration.

The violence of family separations at the USA's borders remains an ongoing issue. ${ }^{113}$ A zero-tolerance policy that violated US law and intended to dissuade individuals from trying to reach the USA placed children in cages and separated them from their adult carers. ${ }^{114}$ This was followed by a failure to reunite families even after court decisions requiring the state to act. ${ }^{115}$ There is immediacy and intimacy to violent family separation, particularly when used as a deterrent against people already in desperate situations. Violence against families and children is illegal, but official Trump administration policy. ${ }^{116}$

Trumps' misogyny is pervasive. ${ }^{117}$ His behaviour is imbued with toxic masculinity, which included his unwillingness to wear a mask during the Covid pandemic. ${ }^{118}$ But he also deploys what Honig refers to as 'ambi-gendering' as a source of political and rhetorical power. ${ }^{119}$ Much of the toxicity is performed in his bombast, his militaristic language, in the normalising of locker-room talk or his discussion of journalist Meghan Kelly '[y] ou could see there was blood

111 D A Graham, A Green, C Murphy and P Richards, 'An oral history of Trump's bigotry' (The Atlantic, June 2019).

112 Washington Post Fact Check \#29,317; A Ayoub and K Beydoun, 'Executive disorder: the Muslim ban, emergency advocacy, and the fires next time' (2016) 22 Michigan Journal of Race and Law 215.

113 J Todres and D Villamizar Fink, 'The trauma of Trump's family separation and child detention actions: a children's rights perspective' (2020) 95 Washington Law Review 377; Caitlin Dickerson, 'Hundreds of immigrant children have been taken from parents at US border' (New York Times, 20 April 2018).

114 Office of The Attorney General, Memorandum for Federal Prosecutors along the Southwest Border (2018).

115 P Repard, 'Judge says government has 'sole' duty to find, reunite immigrant parents, children' (San Diego Union-Tribune, 3 August 2018); see also Order Granting Classwide Preliminary Injunction, Ms L, 310 F Supp 3d at 1145.

116 Todres and Fink (n 113 above) 384

117 Kellner (n 101 above) 71, 76

118 'Trump tells allies his wearing a mask would "send the wrong message," make him look ridiculous' (NBC News, 7 May 2020); C Palmer and R Peterson, 'Toxic mask-ulinity: the link between masculine toughness and affective reactions to mask wearing in the COVID-19 era' (2020) 16 Politics and Gender 1044.

119 Honig (n 7 above) 42, 139; P Elliott Johnson, 'The art of masculine victimhood: Donald Trump's demagoguery' (2017) 40 Women's Studies in Communication 229; Maria Aristodemou, 'Unravelling the Trump virus: on Honig's shell shocked' (Critical Legal Thinking, 30 March 2021). 
coming out of her eyes, blood coming out of her wherever'.120 John Bolton, his former National Security Advisor, suggests that Trump had trouble with women leaders such as Theresa May and Angela Merkel.121 While this does not necessarily set him apart from others, his willingness to be publicly and explicitly misogynistic as President (and as a candidate) emboldens others to give voice to their misogyny while negatively impacting upon women's ability to exist in the public sphere and their capacity to call out others for their behaviour. ${ }^{122} \mathrm{His}$ behaviour did galvanise women's marches and social media campaigns, but it pushed women to retake ground that many assumed won. It also demonstrates the fragility of women's voices and place in the political sphere and their believability, as demonstrated by the 25 women who directly accused Trump of sexual assault or Christine Blasey Ford's testimony against Supreme Court appointee Brett Kavanaugh. ${ }^{123}$ During the \#MeToo movement, where women's believability was being trumpeted, the Trump administration pushed the opposite agenda. 124

Evangelical politics has been a feature of the US system since at least the 1970 s, and, gradually, politicians have aligned their legal political choices with evangelical policy. ${ }^{125}$ For women's rights and particularly their bodily autonomy in the US and globally, this is of immense concern, especially as it impacts on US aid programmes. ${ }^{126}$ Trump's appointments to the judicial benches may have their long-term impact here should US federal courts increasingly align themselves with changes to law which curtail women's bodily autonomy or increase the possibilities of discrimination against particular groups. ${ }^{127}$ There

120 D P McAdams, The Strange Case of Donald J Trump: A Psychological Reckoning (Oxford University Press 2020) 120; J H Rhodes et al, 'Just locker room talk? Explicit sexism and the impact of the access Hollywood tape on electoral support for Donald Trump in 2016' (2020) 37 Political Communication 741.

121 'Trump "has trouble with women leaders", says ex-adviser John Bolton' (Sky News, 25 May 2020).

122 Salmon (n 6 above).

123 M K Maas et al “I was grabbed by my pussy and its\# NotOkay”: a Twitter backlash against Donald Trump's degrading commentary' (2018) 24 Violence Against Women 1739.

124 Honig (n 7 above) 89, 123.

125 A R Schäfer, Countercultural Conservatives: American Evangelicalism from the Postwar Revival to the New Christian Right (University of Wisconsin Press 2011); Charlie Jeffries, 'Adolescent women and antiabortion politics in the Reagan administration' (2018) 52 Journal of American Studies 193; C Gustavo Poggio Teixeira and J Felipe Ribeiro Calandrelli, 'Donald Trump and neoconservantism' (2017) 24 Esboços 380.

126 T McGovern, 'From bad to worse: global governance of abortion and the Global Gag Rule’ (2020) 28 Sexual and Reproductive Health Matters 54.

127 A R A Aiken, 'Erosion of women's reproductive rights in the United States' (2019) British Medical Journal 366. 
are also concerns as regards LGBTQ rights. The increase in anti-trans rights rhetoric, including banning trans individuals from serving in the military, plays a significant role in gendering who ought to be the active political subject of US politics, and who gets to contest within the political sphere. 128

Whether law became the whim of the administration is of central importance. Trump endeavoured to bend law and policy to his whim even when it was illegal. He attempted to reintroduce waterboarding or worse, and he banned Muslims from coming to the USA.129 Over the twentieth century there has been increasing use of executive orders, Trump deploying them is arguably a continuation of the trend of extensive executive power. ${ }^{130}$ While it may have been an attempt to change the office of President, it reflects a trend, and not necessarily a positive one. The pressure placed on Pence to not certify the election results, to reinterpret the law to make it Trump's will, is a further example of an attempt to reinterpret law, to create another reality in Trump's favour. There are also the attempts to deny the election result and the tactical, though failed, use of law to stop the count, or deny the results. All but a few lawsuits failed. Trump and his supporters focused not on the absence of credible evidence or persuasive legal argument, but rather on a supposed corrupt system. In reality, it is merely a system that had yet to fall under his thrall.

\section{TYRANNOPHILIA AND JOHN BOLTON}

Since exiting the Trump administration, John Bolton is vocal in his views of the potential damage that Trump did to US foreign policy and the US Government, but from Bolton's very specific point of view. ${ }^{131}$ From his book it appears Bolton also had concerns while part of the Trump administration. ${ }^{132}$ John Bolton is a well-established critic of the international legal and political order including of the United Nations,

128 A Feuer, 'Justice Department says rights law doesn’t protect gays' (2018) Supreme Court Preview 468; Presidential Memorandum for the Secretary of Defense and the Secretary of Homeland Security, Military Service by Transgender Individuals (25 August 2017) (note that this document was not included in the Federal Register); M J Lang, 'Examining the Trump administration's transgender service ban through an international human rights law framework' (2017) 25 Duke Journal of Gender Law and Policy 249.

129 Honig (n 7 above) 74.

130 D M Driesen 'President Trump's executive orders and the rule of law' (2018) 87 University of Missouri-Kansas City Law Review 489.

131 J Bolton, The Room Where It Happened: A White House Memoir (Simon \& Schuster 2020).

132 Ibid. 
the International Criminal Court and the Iran Nuclear Deal. ${ }^{133}$ His time in the Bush Administration aligned with the acceleration of neoliberal policies of military intervention. ${ }^{134}$ Ideologically, what Trump represents other than unrestrained capitalism and his own aggrandisement is unclear. John Bolton, nonetheless, saw Trump as an avatar for his own ideological outlook and their views on Iran coincided, though Trump did quip that he had held Bolton back from interventionist actions. It could be asked whether Bolton acted from a form of tyrannophilia. 135 That he regarded the Trump administration as an avenue for getting his own political and philosophical agenda into practice and that he believed he could tame the reckless nature of the administration. But, as all who find themselves in that position, he learned that it is impossible to turn the subject into one's ideal 'philosopher' or, in Trump's case, ideal interventionist tyrant.

\section{TYRANNICIDE AND THE FAILURES OF IMPEACHMENT}

Impeachment is partially at least a constitutionalised form of tyrannicide. If there is an aspirant tyrant, impeachment provides a system of halting tyrannical transformation. Impeachment is an invention of English constitutionalism and partly directed at the potential of arbitrary and tyrannical government, albeit it has fallen into abeyance. ${ }^{136}$ Impeachment is not always about tyranny. It can be about forms of treason, bribery, high crimes or misdemeanours that have little to do with tyranny. ${ }^{137}$ In Trump's case, the second impeachment is closer to an act to remove or prevent the return of a tyrant than the first. Nonetheless, both reveal the possibilities and limitations within the US constitutional and political processes for removing a tyrant.

Both impeachment processes unfolded within the dual realities created by the administration. For instance, there was an insistence

133 J R Bolton, 'Should we take global governance seriously' (2000) 1 Chicago. Journal of International Law 205, J Bolton, Surrender is not an Option: Defending America at the United Nations (Simon \& Schuster 2008).

134 J R Bolton, 'The risks and weaknesses of the International Criminal Court from America's perspective' (2001) 64 Law and Contemporary Problems 167; Teixeira and Calandrelli (n 125 above).

135 Lilla (n 21 above) 210-211.

136 Erskine May, Treatise on the Law, Privileges, Proceedings and Usage of Parliament (Charles Knight \& Co 1844); Jack Simson Caird, 'Impeachment' (House of Commons Library CBP7612 2016); F O Bowman III, High Crimes and Misdemeanors (Cambridge University Press 2019) 22.

137 For classical variations on similar processes of account, see M Ostwald, 'The Athenian legislation against tyranny and subversion' (1955) 86 Transactions and Proceedings of the American Philological Association 86. 
that the first impeachment was a hoax and illegitimate. ${ }^{138}$ Trump argued he no longer recognised House Speaker Nancy Pelosi and that Congressman Adam Schiff, one of the main investigators, should be arrested for treason. ${ }^{139}$ While it is natural that those subject to impeachment would argue that it is wrongfooted, the extension of this to undermining the entire system and the corresponding acquiescence of Republicans within Congress established a narrative that passed into the second impeachment which Republican Senator Josh Hawley called a Kangaroo Court. ${ }^{140}$ While neither impeachment was successful, the continued undermining of integrity of the process weakens any future attempts to use it to remove a president from office, and thus of a key potential structural guard against tyranny.

The second impeachment shows the cumulative effects of everything that had gone before, from the first impeachment to the silencing, to fear, to the dual (legal) realities, as well as the threats of violence should have Trump lost the 2016 election. ${ }^{141}$ Incitement of insurrection and Trump remaining 'a threat to national security, democracy, and the Constitution if allowed to remain in office, and [that he] has acted in a manner grossly incompatible with self-governance and the rule of law' is an exceptionally disturbing indictment. ${ }^{142}$ The articles of impeachment referred to both the events of 6 January and a telephone call that "urged the secretary of state of Georgia, Brad Raffensperger, to "find" enough votes to overturn the Georgia Presidential election results and threatened Secretary Raffensperger if he failed to do so'.143 This latter element was part of a year-long campaign, begun well before the election itself, asserting that the election results were inevitably fraudulent if Trump lost. The article of impeachment touches on several elements of the taxonomy of tyranny: the use of fear by way of violence and threats to Secretary Raffensperger; the creation of silence via misleading claims and forcing individuals and groups to accept the Trumpian reality as fact; the undermining of elections to overstay a term in office; and an attempt to create an order the ultimate beneficiary of which is Trump. Some House Republicans accepted that

138 Washington Post Fact Check \#23,564, D Trump, 'When the fake impeachment happened, it was a total fake' (17 September 2020); Fact Check \#15,865, D Trump (2 January 2020).

139 Washington Post Fact Check \#13,171, D Trump (2 October 2019); \#13,955 D Trump (17 October 2019).

140 'Republican senators largely unmoved by Democrats' Trump trial prosecution' New York Post, 11 February 2021).

141 Kellner (n 101 above) 77-78.

142 Article of Impeachment against Donald J Trump (2021) by the United States House of Representatives, 117th Congress, 1st Session.

143 Ibid. 
Trump ought to be impeached, while in the Senate, seven Republicans voted in favour of the articles. In the Senate that vote fell short of the two-thirds required to convict. ${ }^{144}$ Several Republicans who voted in favour of impeachment were called upon to resign. Senate Majority Leader Mitch McConnell delayed the impeachment until Trump was out of office and, while reportedly agreeing that Trump had committed impeachable offences, argued that, as he was out of office, he should not be impeached. ${ }^{145}$

The election succeeded where the US legislative branch did not. The election removed a potential tyrant despite efforts to undermine the results and to dampen turnout. It also succeeded because the judicial branch had not come under the Trump administration's thrall. While the legislative branch continues with investigations into the administration, some members are potentially too reliant on Trump (and Trump not unleashing his supporters upon them) for their own re-election to act against him. Some Republicans whom he has previously viciously attacked now endorse him, including some who became his loudest supporters during the second impeachment.146 Public humiliation serves Trump well. It was the demos who concluded that his time in office, despite his demands, was at an end.

\section{CONCLUSION: ON THE ROAD TO TYRANNY?}

From a gender, poverty and race perspective, there are many in the USA who argue that they live in a tyranny. ${ }^{147}$ However, if the benchmark for tyranny is the operation of the US Constitution, despite everincreasing pressure, tyranny is yet to emerge. Trump is no longer in office, although he may be again in the future. What is more critical than his incumbency of high office is what Trump suggests about the US political and legal order. Just as Julius Caesar did not transform the office of dictator, nor did Trump transform the Office of the President

144 Washington, US Capitol Room H154 (13 January 2021) 'Roll Call 17, Bill Number: H Res 24, 117th Congress, 1st Session'; Office of the Clerk, US House of Representatives: archived from the original on 13 January 2021, retrieved 13 January 2021.

145 Liz Cheney says she won't resign after Wyoming GOP calls for her to step down: archived 9 February 2021, at the Wayback Machine, Washington Times, Valerie Richardson, 7 February 2021, retrieved 7 February 2021; Jonathan Martin and Maggie Haberman, 'McConnell is said to be pleased about impeachment, believing it will be easier to purge Trump from the GOP' (New York Times, 12 January 2021): archived from the original on 12 January 2021, retrieved 12 January 2021.

146 Kellner (n 101 above) 75-77; A Ware, 'Donald Trump's hijacking of the Republican Party in historical perspective’ (2016) 87 Political Quarterly 406.

147 The article has not touched on US foreign relations. 
of the USA. The Office of Roman dictator's demise into tyranny began with Sulla and was compounded by Augustus, after whose death the Roman Republic's structures could not recover. In January 2021, the presidency transitioned to Biden - but with accompanying violence and in the face of an ever-growing proportion of Americans who now believe their election system is fraudulent. The real question is whether Trump fatally undermined the US system. Trump may be re-elected. The litmus test for tyranny will be whether he continues in the same vein and, if so, whether he would continue to enjoy support from enough of the Republican Party to make a third impeachment impossible. Could a third impeachment see him removed, and if he continued in the same vein would the continued support from some parts of the Republican Party make a third impeachment impossible? If Trump were to take steps beyond what occurred under impeachment one or impeachment two, is there a real possibility that a third impeachment would succeed in removing him or has the US system become so unravelled that it would be unable to operationalise its key safeguard of removal? If not Trump himself, could a prospective tyrant be elected in his model? Potentially, is there also a future presidential candidate cloaked in performed legitimacy as the anti-Trump who could then take advantage of the denuded political sphere to install tyranny?

In truth, the most important factor in the potential emergence of (post-)Trump tyranny will be the denuding of the public space and contestation. At the centre of this are the two realities: Trump's and the contested space of public debate. A historical denudation of the latter impacted upon the ability to sustain the former and Trump used the denudation and pushed it even further.148 Within the public sphere of contestation, the role of social media in creating and sustaining Trump's reality is important. Looking forward, it seems the behaviour and regulation of social media companies will play a critical role in creating and sustaining alternative realities and in the fostering of widespread conspiracy theories. Now somewhat chastened by events and with several ultimately banning Trump from their platforms, should Trump run for President again, how would social media companies react? Facebook's appearances before Congress and its adoption of a human rights policy are pre-emptive attempts to stave off regulation. ${ }^{149}$ Facebook admits that it is able to impact on voter

148 T Lynch, 'President Donald Trump: a case study of spectacular power' (2017) 88 Political Quarterly 612.

149 Neema Hakim, 'Do not trust Facebook to enforce human rights' (OpionoJuris, 22 March 2021); Mayank Aggarwal, 'Facebook "behaving like a North Korean dictator" in Australia' (The Independent, 19 February 2021). 
turnout and that is an awesome power to leave entirely unregulated.150 Voting turnout for the last two US presidential elections was very high, but voter suppression is also high. In Georgia, subject of the second impeachment article, a raft of new laws will make it particularly difficult for African Americans to vote. ${ }^{151}$ In Georgia, where Trump attempted to interfere in the counting process and claims of rigging unleashed such fury that an election worker had to go into hiding, this is particularly concerning. 152

Such laws may end up in federal courts, and a further test of the emergence of tyranny will be whether Trump has succeeded in stacking these courts so that they enable such attempts, even if they do not find in his favour in spurious voter fraud petitions relating to the 2020 election. Here, again, the groundwork for Trump was already there, including in the way in which law had evolved to not reign in certain activities like campaign finance, hate speech, institutional violence and inequality, but Trump's presidency exacerbated that process. Law rarely stopped Trump, and it certainly failed to foreclose on his potential future return. Public contestation and the public sphere did more to reign Trump in than law. Nonetheless, the unrelenting denudation, the inability to discern facts amongst the conspiracies and alternative Trumpian reality makes the system ever more precarious. It is arguable that if Pence had failed to certify Biden's election Trump would still be President. That this is contestable shows the extent of the problem.

When examining the events of the past few years, it is important to not get lost in the minutia but to see the whole: we cannot focus only on Trump himself but must see him as part of a broader political and legal context: thus, not just focusing only on Trump but also on the broader legal and political context in which he operates - to consider what aspects enabled him, what aspects of law stopped him, and to contemplate what law's limitations in that context turned out to be. Law is important, but law on its own is not a sufficient buttress against tyranny. Indeed, as outlined above, law and constitutionalism can be enablers of tyranny. A series of questions need to be considered. If Trump had succeeded in stopping the count, would commentators begin to call him an authoritarian constitutional figure, and if not, why not? Why is that a difficult consideration but not for Hungary, Poland, India, Turkey, Russia and others. The answer probably lies in the work of Edward Said and Franz Fanon and others and the use

150 Alex Hern and Julie Carrie Wong, 'Facebook plans voter turnout push - but will not bar false claims from Trump' (The Guardian, 17 June 2020).

151 'Georgia's new voting law triggers legal challenges' (The Economist, 3 April 2021).

152 Honig (n 7 above) 2. 
of knowledge (here of constitutionalism) to describe what is going on elsewhere but to not see it at home. The surprise that greeted Trump's election, and that he withstood two impeachments and might very well return, is only a shock if American (constitutional) exceptionalism is accepted as true. Thick democracy and contestation are absolutely necessary; liberal constitutionalism does not suffice. The lesson here is not that democracy is bad, or that Garett Jones is correct that we should have 10 per cent less of it. The lesson is that taking the health of a democracy for granted and denuding it for short-term gain has long-term consequences.

To finish on a uchronic anecdote: what would have happened if the riot had occurred in December or if Mitch McConnell had not delayed the impeachment process? If Trump were still President, would the Republican Senate have been more or less likely to impeach him? Or another uchronic point: would a secret ballot have altered the outcome? What role did fear, fear of a Trump supporter backlash perhaps, have in the way Senators voted? There is some salve in the idea that Trump did not turn the entire Republican establishment to his needs, but he turned enough of them. James Baldwin, whose assiduous commentary on the negative aspects of the US system remains prescient, stated that '[a] civilization is not destroyed by wicked people; it is not necessary that people be wicked but only that they be spineless'.153 Trump did not bring about US tyranny, but the acquiescence of those around him just might. There are many limits to liberal constitutionalism, and one of them is that if tyrannical intent exists and is beneficial to enough of the elite, liberal constitutionalism will be of little use as a bulwark in the absence of an active political space. 